\title{
Spatial Changes in the Wetlands of Lagos/Lekki Lagoons of Lagos, Nigeria
}

\author{
Jerry Nwabufo Obiefuna ${ }^{1}$, Nwilo, P. C. ${ }^{2}$, Atagbaza, A. O. ${ }^{2} \&$ Okolie, C. J. ${ }^{2}$ \\ ${ }^{1}$ Department of Architecture, University of Lagos, Akoka, Lagos, Nigeria \\ ${ }^{2}$ Department of Surveying and Geoinformatics, University of Lagos, Akoka, Lagos, Nigeria \\ Correspondence: Jerry Nwabufo Obiefuna, Department of Architecture, University of Lagos, Akoka, Lagos, \\ Nigeria.E-mail: jerynus@yahoo.com; jobiefuna@unilag.edu.ng
}

Received: November 22, 2012 Accepted: May 23, 2013 Online Published: June 27, 2013

doi:10.5539/jsd.v6n7p123 URL: http://dx.doi.org/10.5539/jsd.v6n7p123

\begin{abstract}
Lagos metropolis, the current economic capital of Nigeria is a low-lying coastal city endowed with a number of lagoons and wetland ecological assets. Lagos/Lekki Lagoons being the largest with a combined size of $646 \mathrm{~km}^{2}$ are fringed on many sides by wetlands. Many of these wetlands have undergone severe spatial changes from rapid urbanization in the past three decades. The precise nature of these changes is largely unknown and unreported. As the area is experiencing intense development pressure, this study therefore examined the spatial changes in the wetlands fringing these lagoons using the integrated approach of remote sensing data and GIS with topographic maps providing baseline data. The objective is to quantify and establish the precise location and magnitude of these changes over the years from 1984 to 2006. Two types of wetlands are prevalent in the Lagos area namely: the swamps and mangroves. ENVI software was used along with parallelepiped supervised classification in processing the Landsat images. Results show that the mangrove wetlands decreased from $88.51 \mathrm{~km}^{2}$ to $19.95 \mathrm{~km}^{2}$ at $-3.12 \mathrm{~km}^{2}$ annually while swamps decreased from $344.75 \mathrm{~km}^{2}$ to $165.37 \mathrm{~km}^{2}$ at $8.15 \mathrm{~km}^{2}$ annually both between 1984 and 2006. Results further show that mangroves which were widespread in seven council areas around these lagoons in 1984, have dwindled to only four councils in 2006 . These decreases are attributable to urban development pressures. Some of the implications of these losses and conservation issues are briefly highlighted.
\end{abstract}

Keywords: lagoons, wetlands, spatial changes, remote sensing, GIS

\section{Introduction}

\subsection{Background}

As part of natural ecosystem, wetlands where they occur in the landscape are valued for their contribution to ecological balance and biodiversity. Also, they are valued for the numerous goods and functions delivered freely to the ecosystem and human habitats which include flood storage and distribution, retention of sediments and nutrients, aquifer recharge, water quality improvement, aesthetic and educational benefits among others (Kindscher et al., 1998; USEPA, 2009). Unrestrained degradation of wetlands and ecosystem will inevitably lead to a loss or diminution of some or all of these functions.

Wetlands are land areas covered with water or where water is present at or near the soil surface all year or varying periods of the year. These areas support the prevalence of hydrophytes or aquatic plants that are typically adapted to life in water saturated (hydric) conditions (USEPA, 2009). Wetlands include a variety of habitats such as marshes, peat lands, flood plains, rivers and lakes, coastal salt marshes, mangroves and sea grass beds, coral reefs and other marine areas no deeper than six meters $(6 \mathrm{~m})$ at low tide. They also include human-made wetlands such as waste-water treatment ponds and reservoirs (Ramsar Convention Secretariat. 2007a). Urban populations and wetlands are said to have been engaged in a turbulent, somewhat symbiotic marriage since the dawn of civilization. Being essential for human well - being, wetlands have been progressively lost and degraded from human activities since then. The rate of their loss is known to be greater than for any other type of ecosystem (UN - Habitat, 2010).

Metropolitan Lagos, the current economic capital of Nigeria and some of its suburbs have developed on a coastal environment characterized by low-lying tidal flats, estuaries, wetlands and sandy barrier beaches, some of which were reclaimed haphazardly for development (Abegunde, 1988). Spurred by demand for land for rapid urbanization, Abegunde (1988) further suggested that this unplanned and extensive reclamation of wetlands, 
sand filling of lagoon shores, excessive dredging, encroachment on natural drainage channels and unrestrained deforestation have all been significant features of metro Lagos. Adeniyi (1980) had earlier observed that over $87 \%$ of vacant wetlands in metro Lagos between 1962 and 1974 had been converted to high density unplanned residential housing.

This uncontrolled urban expansion in an unsystematic manner has had serious repercussions on the environmental quality of many parts of the metropolis. Brody et al. (2007) submitted that rising population density in coastal area is usually associated with greater amounts of impervious surfaces, alteration of watersheds, coupled with diminished capacity of these systems to naturally hold surface runoff. The Lagos/Lekki Lagoons are the largest of the coastal barrier - lagoon complex which extends $200 \mathrm{~km}$ eastward from the Nigeria/Benin Republic border (Ibe, 1988). With a combined size of $646 \mathrm{~km}^{2}$, they are fringed on many sides by wetlands. As the area has been and is still experiencing intense development pressure, many of these wetlands have undergone severe spatial changes from rapid urbanization in the last three decades. But like in many coastal cities of the world, the precise impacts of these human activities on coastal wetlands are poorly understood (James et al., 2007). In this case, the precise nature of these changes is largely unknown and unreported. Although Odunuga \& Oyebande (2007), Taiwo \& Areola (2009) provided recent useful insights into wetland conversion in parts of the Lagos coastal area, a comprehensive study which assessed quantitatively the spatial changes in the wetlands of Lagos/Lekki Lagoons and their consequences is yet unreported in the literature. Besides, any conceptualization of comprehensive wetland monitoring and conservation in the area ought to be preceded by the inventory and establishment of their changes, what remains and their locations. These were the impetus for this study.

This study therefore assessed the spatial changes in the wetlands fringing these lagoons. The objective is to quantify and establish the precise locations, magnitude and trend of these changes over the years from 1984 to 2006. In doing so, the study sought to answer these questions namely: (i) what is the extent of wetlands fringing these lagoons at the base year and how have these changed in recent times? (ii) what are the implications of these changes?

\subsection{Urbanization \& the Need to Assess Wetland Loss}

Urbanization which is the conversion of land to uses associated with growing population and economy has been recognized as having a world - wide trend. More than $50 \%$ of the world's population currently resides in cities and urban settlements with this shift to urban living expected to continue at rates of almost $1.6 \%$ per annum worldwide. The highest urbanization rates were expected in developing and least developed countries (UN-Habitat, 2010) while $95 \%$ of the net increase in global population would be in cites of the developing world (Zhang et al., 2008) such as Lagos. As part of this trend, the coastal zones are known to be home to nearly $75 \%$ of the global population (Asangwe, 2006).

Lagos city has grown from a settlement of about $3.85 \mathrm{~km}^{2}$ in 1881 to a huge metropolis of over $1,183 \mathrm{~km}^{2}$ in 2004 (Okude \& Ademiluyi, 2006). In consequence, the population which was negligible in those years had risen from about 5.7million in 1991 to about 9.1million in 2006 (National Population Commission, 2006) with average population density of 20,000 persons $/ \mathrm{km}^{2}$ (Presidential Committee on the Redevelopment of Lagos mega-city Region, 2006). The nature of population growth in some of the local councils around the two lagoons between 1991 and 2006 is reflection of the urbanization pressure in the study area (Table 1). For instance, while Ikorodu council area which is rapidly developing had a population density of 7,207 persons $/ \mathrm{km}^{2}$ in 2006 , Etiosa LGA had $3,423 / \mathrm{km}^{2}$, while densely developed Lagos Mainland, Shomolu and Lagos Island LGA's had densities of 28,154; 39,053 and 39,661persons $/ \mathrm{km}^{2}$ respectively in 2006 (Mehrotra et al., 2009). The obvious consequence of this population expansion on natural resources in a coastal terrain with about $44 \%$ of the study area being water bodies and wetlands in 1984 (Figure 1) is development on marginal lands within or fringing urbanized areas.

Rapid urbanization and urban areas are known to generate negative impacts on the environment (UN-Habitat, 2010) as they lead to changes in landscape patterns, ecosystem functions and their capacity to perform functions in support of human populations. This is especially so when rapid or unplanned growth occur in areas of highly vulnerable systems such as wetlands. The conversion of large tracts of wetlands into built - up area results in increased impervious surfaces which can lead to flooding and altered aquifer recharge (Odunuga \& Oyebande, 2007). Quantifying such changes in the landscape patterns can be useful in tracking the capacity of natural ecosystems to render services in support of human systems (Flores, Olivas \& Chavez, 2008). It is also necessary as inputs to environmental resource planning, management and sustainable development.

Fortunately, the development of remote sensing along with GIS provides a rich data source and a powerful analytical tool towards understanding the structure, function and dynamics of landscapes on the earth's surface. 
The integration of remote sensing and GIS has made possible the systematic inventory and assessment of land resource and land degradation over space and time for intervention strategies to be instituted to safeguard the health of ecosystem (Fasona, Omojola \& Onyeahialam, 2007). Also integrating temporal satellite data, GIS and historic maps provide effective monitoring tools for land usage as they provide firm portrayal of growth patterns and how development results in profound changes to the landscape (Olaleye, Abiodun \& Igbokwe, 2009). Remote sensing have been widely used to observe and record the earth's land and water surfaces through the means of reflected or emitted electromagnetic energy (Jensen, 2007; Campbell, 1996). Recent advances in sensor design and data analysis are making remote sensing very practical and attractive for monitoring natural and anthropogenic wetland changes (Klemas, 2011)

To inventory, monitor and model spatial locations and changes in earth's resources require a dynamic tool beyond the capabilities of the traditional paper maps and overlays. Geographic Information System (GIS) which has its roots in this traditional map and cartographic process offers that tool. It is a computer system with appropriate software for capturing, storing, querying, manipulating, analyzing and displaying geospatial or geographically referenced multi-thematic data in raster or vector formats from many sources (Chang, 2006). Geospatial or geographically referenced data are data which describe locations (where is) and characteristics (attributes) of spatial features on the earth's surface. GIS is therefore a combination of spatial and attribute data.

Wetlands as critical and sensitive land cover have variously been studied and assessed with remote sensing data. Because of repetitive coverage, satellite remote sensing has provided a tool for inventory, mapping and assessment of wetlands over large geographical areas. It has become appropriate for inventorying and monitoring wetlands in developing countries where funds are limited and scanty information is available on wetland areas and their losses over time (Ozesmi \& Bauer, 2002). Almost every type of wetland has been studied with satellite imagery. But only few of these studies have been reported in a developing country like Nigeria. In these studies, multi-temporal imageries often aided classification of wetlands as well as their separation from other land cover classes. Included in the types of wetlands studied with remote sensing are marshes, swamps, lagoons, coastal tidal marshes, mangroves and other coastal wetlands, bogs and fens, inland freshwater marshes, forested wetlands or swamps, open water areas, wet meadows and submerged aquatic vegetation.

Some of the recent studies to identify or monitor wetlands and their changes with remote sensing and GIS, involve the assessment of the extent and changes in the mangrove ecosystem of Niger Delta (James et al., 2007); the detection of change in the lower Ogun River flood Plain (Odunuga \& Oyebande, 2007); monitoring of land degradation along Ondo Coastal Zone of Nigeria (Abbas, 2008); the monitoring of wetlands in the semi-arid west, USA (Neale et al., 2007); the mapping of Canada's wetland with optical, radar and DEM data (Li \& Chen, 2005); the inventory, monitoring of temporary and permanent wetlands of Western Cape, South Africa (De Roeck et al., 2008) and the spatial - temporal analysis of wetland losses in the Lagos Coastal region (Taiwo \& Areola, 2009).

Table1. Population figures for some LGA's around the lagoons

\begin{tabular}{ccc}
\hline Local government area & $\begin{array}{c}\mathbf{1 9 9 1} \\
\text { Population } \\
\text { Census }\end{array}$ & $\begin{array}{c}\mathbf{2 0 0 6} \\
\text { Population } \\
\text { Census }\end{array}$ \\
\hline Amuwo-Odofin & 225,823 & 328,975 \\
Apapa & 154,477 & 222,986 \\
Eti-Osa & 157,387 & 283,791 \\
Ikorodu & - & 535,619 \\
Kosofe & 412,407 & 682,772 \\
Lagos Island & 165,996 & 212,700 \\
Lagos Mainland & 273,079 & 326,700 \\
Shomolu & 358,787 & 403,569 \\
\hline
\end{tabular}

Source: National Population Commission of Nigeria, 2006. 


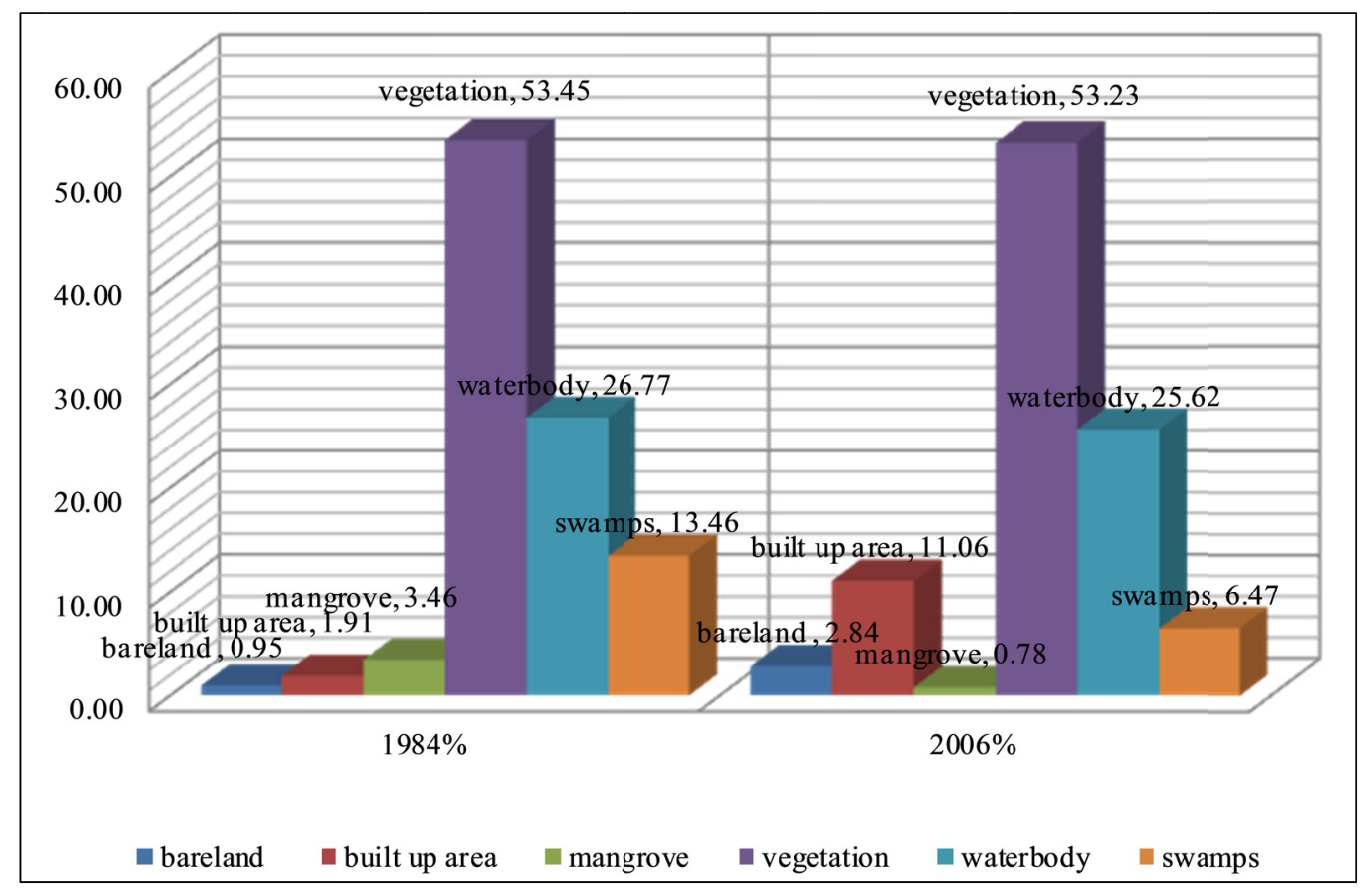

Figure 1. Percentage Land cover changes in the study area 1984 - 2006

Source: Obiefuna et al. (2013).

\section{Method}

2.1 The Study Area

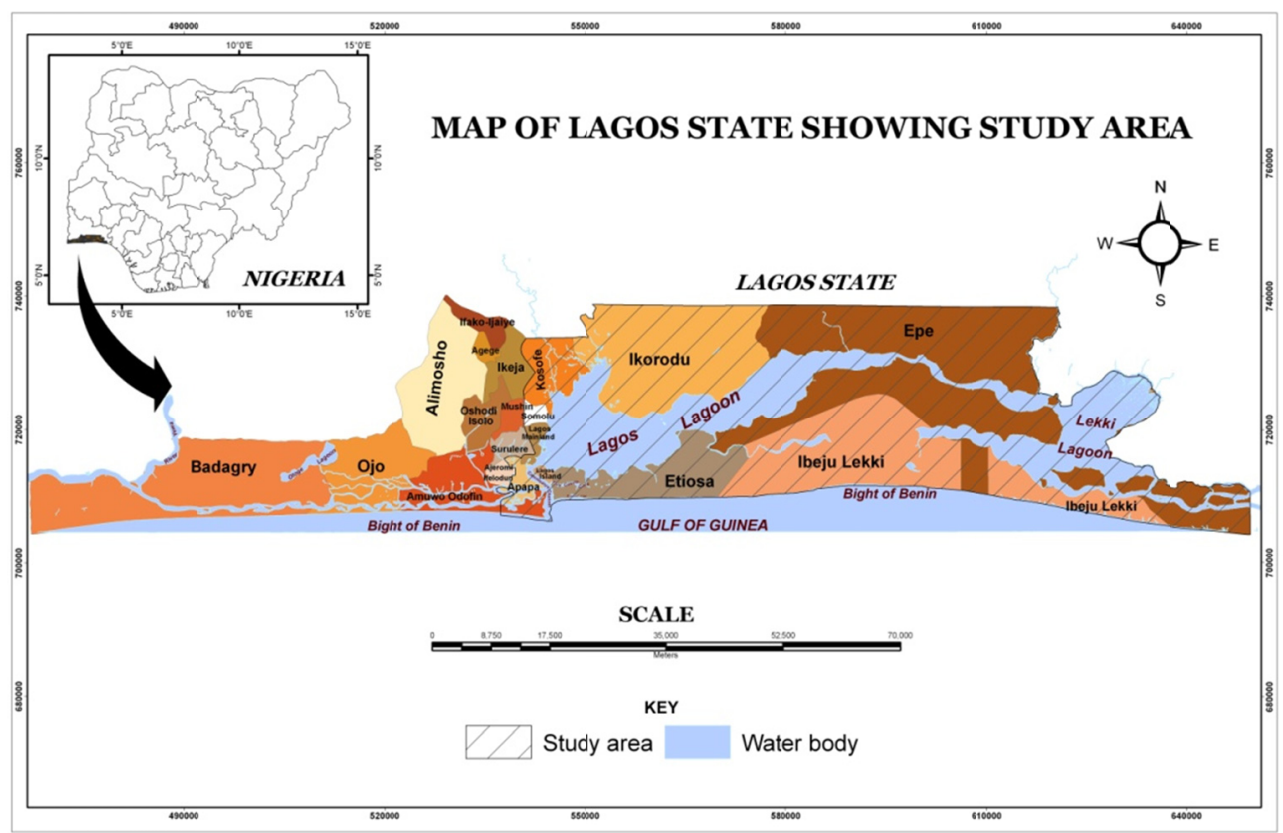

Figure 2. Map of the study area

Source: Federal Surveys 7.5' Topographic Series, 1984.

The study area covers the eastern half of Lagos State which constitutes about $71 \%$ of the total area of the state of about $3632 \mathrm{~km}^{2}$ (Figure 1) The location is at about Latitude $6^{\circ} 23^{\prime} \mathrm{N}$ and $6^{\circ} 42^{\prime} \mathrm{N}$ and Longitude $3^{\circ} 20^{\prime} \mathrm{E}$ and $4^{\circ} 20^{\prime} \mathrm{E}$ and while covering an area of about $2561.26 \mathrm{~km}^{2}$ of land and water. On the north and east, it is bounded 
by Ogun State. On the south, it is bounded by Bight of Benin/Atlantic Ocean. Both Lagos and Lekki Lagoons have a combined size of $646 \mathrm{~km}^{2}$. The only western outlet for the two lagoons is through Commodore Channel which links Lagos Lagoon to Bight of Benin/Atlantic Ocean. With direct connection to the sea, salinity is generally higher in Lagos Lagoon and the waters are brackish while the Lekki Lagoon is of fresh water (Ibe, 1988; Oyebande et al., 2004). Two arms of Lekki Lagoon connect the Niger Delta in the east. Two major wetland regimes identified in Oyebande et al. (2004) namely the Lagos/Lekki Lagoon wetlands and the Ogun River wetlands are in the area. The climate of the area is controlled alternately by both the wet tropical maritime air mass (from the Atlantic Ocean) and dry tropical continental air mass from Sahara Desert. Of the 20 Local Government Areas (LGA's) in the state, 10 are coterminous with these lagoons and their western outlet. These include part of Amuwo - Odofin, Apapa, Epe, Etiosa, Ibeju/Lekki, Ikorodu, Kosofe, Lagos Island, Mainland and Shomolu LGA's.

\subsection{Data and Image Processing}

Due to lack of digital data, several hardcopy 1:25,000 topographic maps were scanned, geo-referenced and digitized for baseline data. The digitized maps were then edge - matched to produce a seamless mosaic. This vectorised mosaic was thoroughly cross-checked for errors and then input into ArcGIS for editing and area calculations. Two scenes of Landsat TM (Thematic Mapper) of $18^{\text {th }}$ December, 1984 and $\mathrm{ETM}^{+}$(Enhanced Thematic Mapper) of December 2006 were processed to extract the wetlands, mangroves and water bodies across the area of study. Bands 3, 4 and 5, were used for colour composite in order to identify the wetlands, mangroves and water bodies distinctly.

The image classification technique used was the supervised classification. The supervised classification was chosen over the unsupervised classification because of the ease at which the former identifies the wetlands and/or water bodies and also because this simplifies the editing stage. In supervised classification, pixels are clustered in a dataset into classes corresponding to user-defined training samples. The parallelepiped classification technique which uses a simple decision rule to classify multispectral data was employed. The wetlands were identified as having a greenish spectral signature, while the mangroves had the dark green colour as their trademark. With field and ancillary data, these were then uniquely assigned as regions of interest or training samples. Using ENVI (Environment for Visualizing Images) software, a parallelepiped supervised classification was then carried out on the trained classes and then used to extract the wetlands from the entire multispectral imageries of the two dates independently.

After the classification exercise, the output showed only the wetlands and a few other features picked as a result of similar spectral reflectance. A post classification auto vectorization of the output was executed. The vectorized wetlands were then exported to Arcmap as shapefiles for editing, change detection and calculation of areas.

\section{Results}

Results show that mangroves decreased by about $77 \%$ from $88.51 \mathrm{~km}^{2}$ to $19.92 \mathrm{~km}^{2}$ at $3.12 \mathrm{~km}^{2} / \mathrm{yr}$ deficit while swamps decreased by $52 \%$ from $344.74 \mathrm{~km}^{2}$ to $165.37 \mathrm{~km}^{2}$ at a loss of $8.15 \mathrm{~km}^{2} / \mathrm{yr}$ both between 1984 and 2006 (Table 2). Results further show that the mangroves which were widespread in 7 (seven) LGA's in 1984 have dwindled to only 4 LGA's in 2006 with about $4 \mathrm{~km}^{2}$ and above. Epe, Etiosa, Ikorodu and Kosofe in that order were the councils with the largest area of mangroves in 1984 of $24.76 ; 22.65 ; 19.43$ and $17.94 \mathrm{~km}^{2}$ respectively. Similarly, swamps which had sizeable presence in five (5) LGA's in 1984 had whittled to four councils with about half of their sizes converted in 2006. The relative loss of wetlands (mangrove and swamps) and gains by succeeding land cover mainly bare land and built - up areas are displayed in Figure 1.

Table 2. Area - wide wetland changes from $1984-2006$

\begin{tabular}{ccccc}
\hline Land cover & $1984\left(\mathrm{~km}^{2}\right)$ & $2006\left(\mathrm{~km}^{2}\right)$ & Change $\left(\mathrm{km}^{2}\right)$ & \% Rate of Change (1984-2006) \\
\hline Swamps & 344.75 & 165.37 & -179.37 & -52.03 \\
Mangroves & 88.51 & 19.95 & -68.59 & -77.50 \\
Total area & 433.26 & 185.32 & & \\
\hline
\end{tabular}

Total study area $=2,561.26 \mathrm{~km}^{2}$. 


\section{Discussion}

The highest decline in mangroves was recorded in Epe LGA where it declined at $0.95 \mathrm{~km}^{2} / \mathrm{yr}$ deficit followed by Etiosa where it receded by $0.82 \mathrm{~km}^{2} / \mathrm{yr}$ (Figure 3 ; Table $3 \mathrm{a}, \mathrm{b}$ ). The highest decline in swamp wetlands occurred in Epe and Ibeju-Lekki councils at a rate of loss of $3.27 \mathrm{~km}^{2} / \mathrm{yr}$ followed distantly by Ikorodu LGA where they were converted at $1.02 \mathrm{~km}^{2} / \mathrm{yr}$ (Figure 4; Table 3a, b). The main drivers of this conversion both in the north and south of the Lagos Lagoon have been determined in Obiefuna et al. (2013) to be principally urban development. Consequently, the disappearance of the mangroves in the western part of Etiosa LGA for example, is traceable to developments kick-started through the Lekki Peninsula Residential Scheme 1 in 1980's. The distribution of mangroves around the Lagos Lagoon attests to the brackish nature of the lagoon waters and possibly symptomatic of the extent of marine intrusion from the Atlantic Ocean. Conversely, its absence around the Lekki Lagoon is indicative the lagoon is of fresh water. The remnants of mangroves and swamps along Omu Creek in Etiosa and Ibeju -Lekki LGA's (north of Lekki - Epe Expressway) are currently under stress from residential development accelerating in the area (Plate 1a, b).

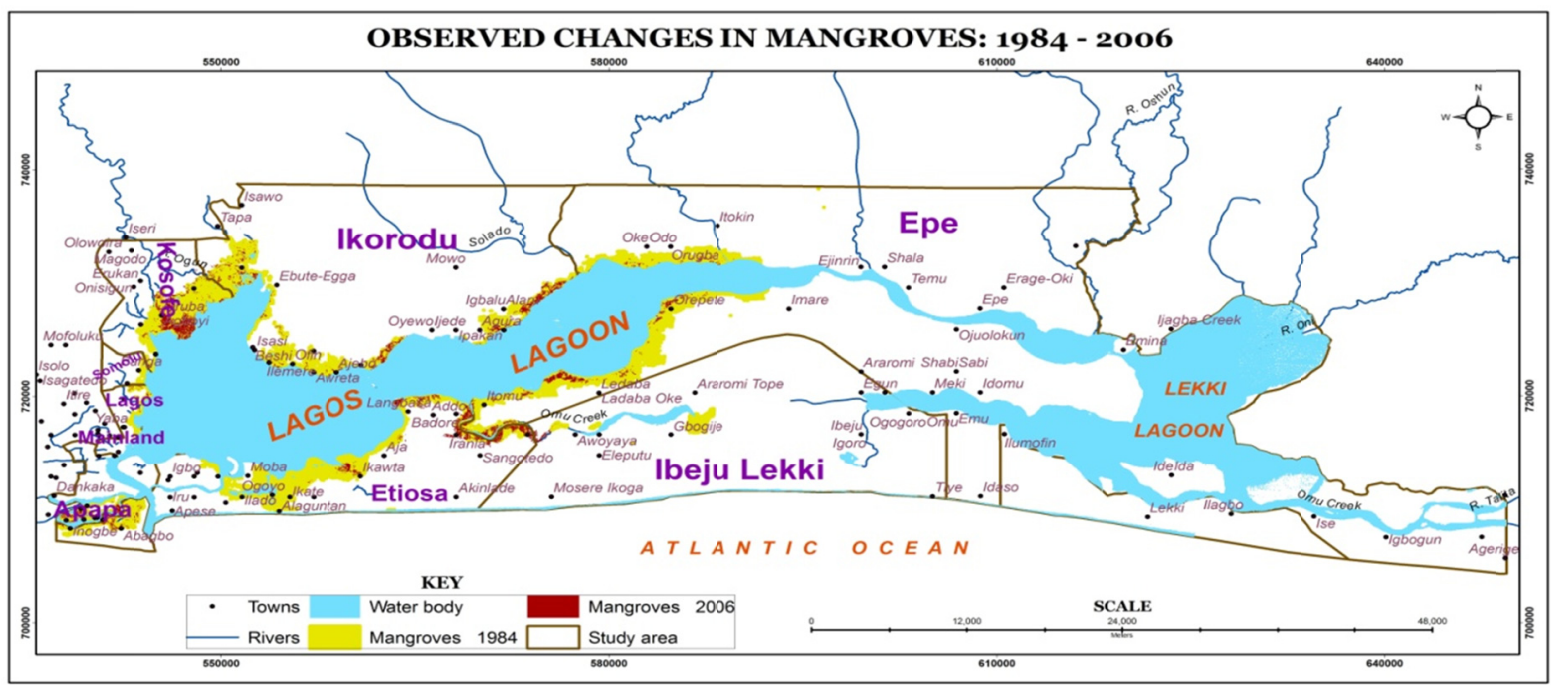

Figure 3. Changes in mangroves between 1984 and 2006

Table 3a. Coverage of swamps and mangroves per LGA in 1984

\begin{tabular}{ccccc}
\hline LGA & Swamp $\left(\mathrm{km}^{2}\right)$ & $\%$ & Mangrove $\left(\mathrm{km}^{2}\right)$ & $\%$ \\
\hline Amuwo odofin & 0.06 & 0.02 & 3.16 & 2.30 \\
Apapa & 0.01 & 0.00 & 24.76 & 2.60 \\
Epe & 163.38 & 47.39 & 22.65 & 27.98 \\
Etiosa & 12.69 & 3.68 & 1.55 & 25.59 \\
Ibeju Lekki & 125.78 & 36.48 & 17.20 & 1.75 \\
Ikorodu & 41.23 & 11.96 & 15.87 & 19.43 \\
Kosofe & 1.58 & NIL & NIL & NIL \\
Lagos Island & NIL & NIL & 0.73 & 0.83 \\
Mainland & NIL & NIL & 0.29 & 0.32 \\
Somolu & NIL & 100 & 88.51 & 100 \\
TOTAL & 344.75 & & & \\
\hline
\end{tabular}


Table 3b. Coverage of swamps and mangroves per LGA in 2006

\begin{tabular}{ccccc}
\hline LGA & Swamp $($ Sqkm $)$ & $\%$ & Mangrove $(\mathrm{Sqkm})$ & $\%$ \\
\hline Amuwo odofin & NIL & NIL & 0.88 & 0.95 \\
Apapa & NIL & NIL & 3.93 & 4.79 \\
Epe & 91.37 & 55.25 & 4.52 & 19.70 \\
Etiosa & 1.12 & 0.68 & 0.46 & 22.68 \\
Ibeju Lekki & 53.94 & 32.62 & 4.70 & 2.31 \\
Ikorodu & 18.87 & 11.41 & 4.35 & 23.57 \\
Kosofe & 0.07 & 0.04 & NIL & 21.82 \\
Lagos Island & NIL & NIL & 0.14 & NIL \\
Mainland & NIL & NIL & NIL & 0.70 \\
Somolu & NIL & NIL & 19.95 & NIL \\
TOTAL & 165.37 & 100 & & 100 \\
\hline
\end{tabular}

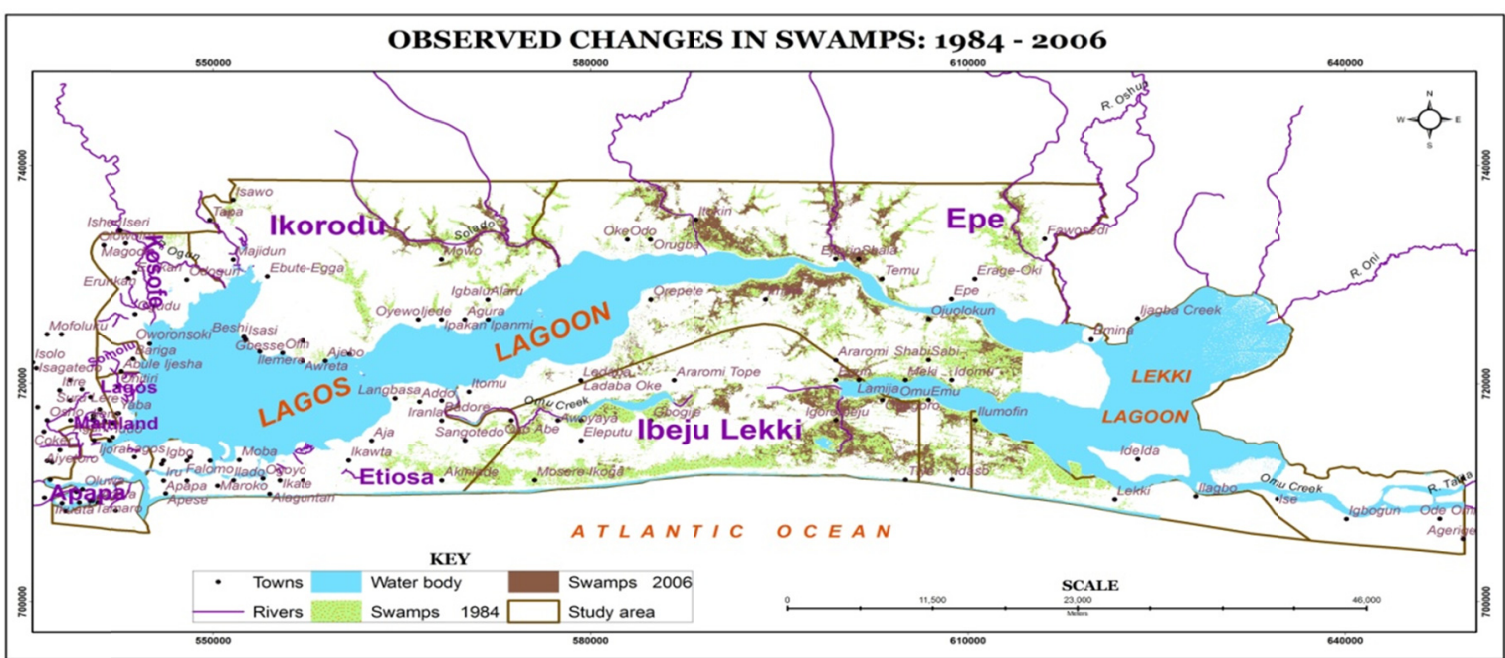

Figure 4. Changes in swamps between 1984 and 2006

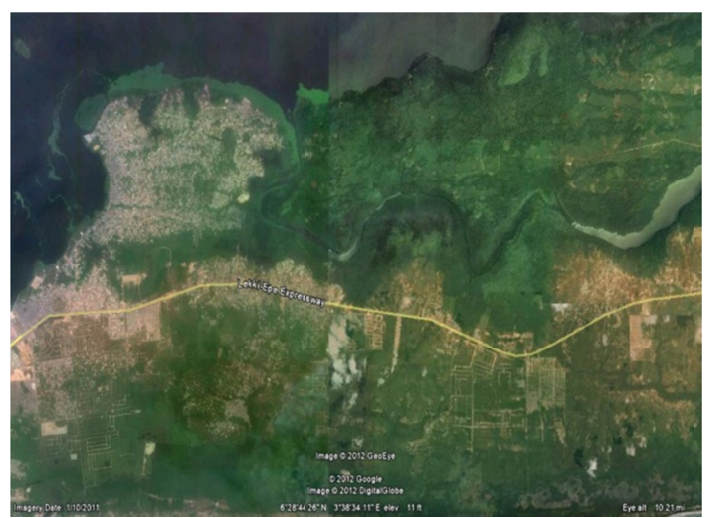

Plate 1a. Development pressure on Omu Creek

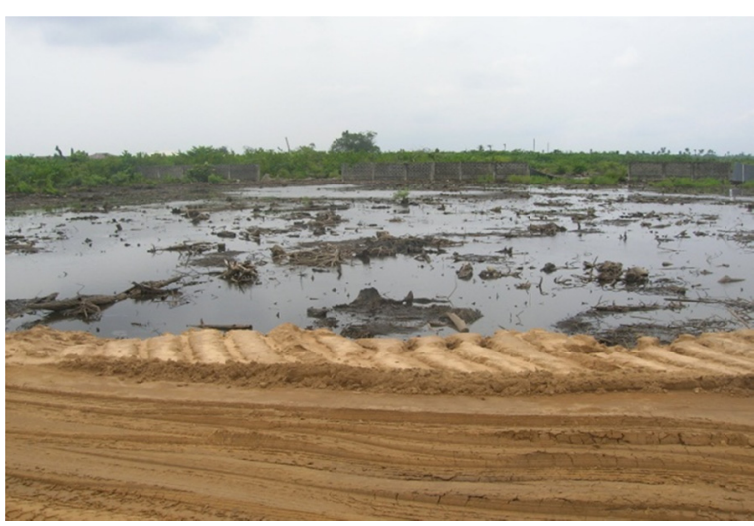

b. Wetland reclamation around Omu Creek in Etiosa LGA Source: Google Earth, 2012.

This rapid depletion of wetlands in the Lagos area has many implications. First, if the rate of conversion of mangroves observed in the study area persists, the remaining mangroves would be wiped out in 2013 if their locations are readily accessible. Similarly, the swamps will be completely lost in twenty one years that is, by 2027. Some other implications of the loss of wetlands include loss of biodiversity, ecological services, flood retention and reduced aquifer recharge, loss of breeding grounds and livelihoods. The depletion of wetlands and 
their dependent species not only translates into biodiversity loss but also into loss of carbon sink, substrate nutrient recycle and other ecological services. An economic implication of the loss of mangroves is the loss of tidal breeding grounds for several fish species (Okude \& Ademiluyi, 2006). This impacts on the food web through the loss of sources of fish protein in addition to disruption in livelihoods of fishermen. Furthermore, ecological services such as flood retention will be severely impaired resulting in inundation of low - lying developed areas. As noted in previous studies, rapid and unplanned reclamation in Lagos (Adelekan, 2009), the destruction of mangroves and wetlands has reduced their flood storage capacity, thus leading to increased flooding (UN - Habitat, 2010; Uluocha \& Okeke, 2004). The perennial flooding experienced in parts of the metropolis therefore may have been exacerbated by wetland degradation, increased impervious surfaces, inadequate and inappropriate drainage structures with improper drainage heads (Awosika et al., 2000) possibly with effects from sea level rise resulting from climate change (Plate 2). With their filtering and purifying mechanisms, the degradation of wetlands poses grave threats to both surface and substrate water quality and volume in the area (Uluocha \& Okeke, 2004).

The rapid rate of loss of wetlands and the attendant consequences necessitate urgent action to conserve the few remaining ones along the visions sustained in the area by Lekki Conservation Center/Nigerian Conservation Foundation (NCF). Although the legal and institutional frameworks for wetland conservation are in place in the country, Oyebande et al. (2004) made submissions on their effectiveness to the effect that: a) Wetland conservation in Nigeria as a whole still lags behind their exploitation and degradation; b) the greatest problem confronting wetland conservation continues to lie in the inadequate capacity to enforce existing environmental laws either at the local council, state or federal levels; c) initiatives to conserve the wetlands previously have been driven largely with financial support of international organizations such as IUCN, WWF and development partners in conjunction with NCF. Although the ministries of environment at the state and federal levels are presently active in environmental issues, little appear to have changed over the years in the conservation initiatives.
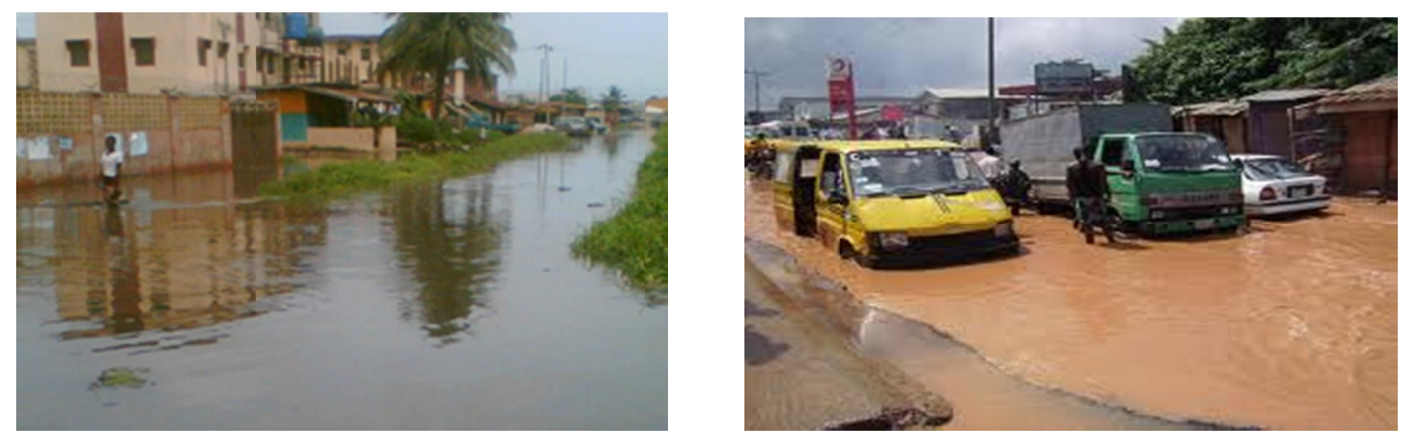

Plate 2. Flooding in parts of the metropolis from wetland reclamation, imperviousness, inappropriate drainage and heads

\section{Conclusion and Recommendations}

Clearly more than half of the store of mangroves and swamps in the study area has been decimated within the study period, consumed ostensibly by urban development. At the local council level, the surviving mangroves in order of magnitude are found in Ikorodu, Etiosa, Kosofe and Epe LGA's, all on the Lagos Lagoon. Likewise, the remaining swamp wetlands are in order of magnitude also largely in four local councils. These are Epe, Ibeju-Lekki, Ikorodu and Etiosa LGA's. The wetlands of the Lekki Conservation Center run by the Nigerian Conservation Foundation (NCF) which is now totally rimmed by urban development, is part of the remaining wetlands in Etiosa LGA.

The increasing flooding in the metropolis from imperviousness and extreme events linked to climate change calls for more proactive measures to conserve the surviving wetlands for flood storage and other ecological capital. To do this requires appropriate inventory and mapping at requisite scale. Fortunately, the LIDAR mapping project of the State is a ready data bank for this and other purposes if available in the public domain. Possibly, the state authorities through the ecological fund could compensate and acquire for public interest the remaining critical mangroves and swamps in their inventoried local councils. Responsible non - governmental organizations (NGO's), corporate bodies, tertiary institutions in the state may be prevailed upon to adopt, conserve and manage some of these for research, recreation and corporate social responsibility. With accumulated experience in 
conservation, it is conceivable that the LCC/NCF may be willing to expand their coverage area if funded and encouraged to do so. Being private sector driven, they may also provide a platform for comprehensive management of the remaining wetlands if provided the enabling environment.

An area for further enquiry arising from this study involves the modelling of the contribution of wetland loss to flooding in the metropolis. Sequel to the completion of the bathymetric mapping of the Lagos Lagoon, it is imperative to inquire into the water storage capacity of these lagoons between the rainy and dry seasons along with bottom accretion rate. These information seem to be lacking in published works.

\section{Acknowledgement}

*Funds for this research were provided by the Central Research Committee (CRC), University of Lagos, Akoka, Lagos, Nigeria.

\section{References}

Abbas, I. I. (2008). Use of Satellite Remote Sensing and Geographic Information Systems to Monitor Land Degradation along Ondo Coastal Zone (Nigeria). Balwois, Orid, Macedonia, 27, 1-13. Retrieved from www.balwois.com/balwois/administration/full_paper/ffp-1137.pdf

Abegunde, M. A. A. (1988). Shoreline Erosion and Land Use Management on the Active SandyBarrier Beaches around Lagos: A New Focus in Environmental Management. In P. O. Sada, \& F. O. Odemerho. (Eds), Environmental Issues and Management in Nigerian Development. Evans Brothers, Ibadan 231-238.

Adelekan, I. O. (2009). Vulnerability of Poor Urban Coastal Communities to Climate Change in Lagos, Nigeria. Paper presented at the Fifth Urban Research Symposium, Marseille, France, June 28-30, 2009.

Adeniyi, P. O. (1980). Land-use Change Analysis Using Sequential Aerial Photography and Computer Techniques. Photogrammetric Engineering and Remote Sensing, 46(11), 1447-1464. Re-issued in Adeniyi, P.O. 2009. Geoinformation Technology and Development: A Compendium of Selected Papers.

Asangwe, C. K. (2006). The Douala Coastal Lagoon Complex (p. 14). Cameroon: Environmental Issues. Retrieved from www.fig.net/pub/figpub/pub36/chapters/ chapter_9.pdf

Awosika, L., Adekoya, E. A., Adekanmbi, M. A., Dublin- Green, C. O., Folorunsho, R., \& Jim- Saiki, L. (2000). Study of Main drainage channels of Victoria and Ikoyi Islands in Lagos, Nigeria and their Responses to Tidal and Sea Level Changes. UNESCO - CSI: Environment and Development in Coastal Regions and Small Islands (p. 108). http://www.unesco.org/csi/act/lagos/drains2.htm

Brody, S. D., Highfield, W. E., Ryu, H. C., \& Spanel-Weber, L. (2007). Examining the Relationship between Wetland Alteration and Watershed Flooding in Texas and Florida. Natural Hazards, 40, 413 - 428. http://dx.doi.org/10.1007/s11069-006-9003-3

Campbell, J. B. (1996). Introduction to Remote Sensing (2nd ed., p. 622). Tailor and Francis, London.

Chang, Kang-tsung. (2006). Introduction to Geographic Information Systems (p. 432). McGraw Hill, New York.

De Roeck, E. R., Verhoest, N. E. C., Miya, M. H., Lievens, H., Batelaan, O., Thomas, A., \& Brendonck, L. (2008). Remote Sensing and Wetland Ecology: a South African Case Study. Sensors, 8, 3542 - 3556. http://dx.doi.org/10.3390/s8053542

Fasona, M., Omojola, A., \& Onyeahialam, A. (2007). Mapping Land Degradation and Forest Resource Loss from Fused Landsat TM and Nigeria sat -1 Images in some parts of the Southwest Coast of Nigeria. In M. Owe \& C. Neale (Eds). Proceeding of Symposium on Remote Sensing For Environmental Change Detection. IAHS Publication 31: 110-118.

Flores, E. S., Olivas, A. G., \& Chavez, J. (2008). Land Cover Change and Landscape Dynamics in the Urbanizing Area of a Mexixan Border City. ASPRS 2008 Annual Conference, Portland, Oregun. 9p.

Fuller, L. M., Morgan, T. R., \& Aichele, S. S. (2005). Wetland Delineation with Ikonos High-Resolution Satellite Imagery, Fort Custer Training Center, Battle Creek, Michigan USGS Scientific Investigations Report 2006 5051, p. 8. Retrieved from http://pubs.water.usgs.gov/SIR2006-5051

Ibe, A. C. (1988). Coastline Erosion in Nigeria (p. 217). Ibadan, Nigeria: Ibadan University Press.

James, G. K., Adegoke, J. O, Saba, E., Nwilo, P. C., \& Akinyede, J. (2007). Satellite-Based Assessment of the Extent and Changes in the Mangrove Ecosystem of the Niger Delta. Journal of Marine Geodesy, 30, 249-226. http://dx.doi.org/10.1080/01490410701438224

Jensen, J. R. (2007). Remote Sensing of the Environment: An Earth Resource Perspective (2nd ed). Pearson 
Prentice Hall, Upper Saddle River, N.J. 07458, 592p.

Kindscher, K., Fraser, A., Jakubauskas, M. E., \& Debinski, D. M. (1998). Identifying Wetland Meadows in Grand Teton National Park Using Remote Sensing and Average Wetland Values. Wetlands Ecology and Management, 5, 265-273. http://dx.doi.org/10.1023/A:1008265324575

Klemas, V. (2011). Remote Sensing of Wetlands: Case Studies Comparing Practical Techniques. Journal of Coastal Research, 27(3), 418-427. Retrieved from http://aswm.org/pdf_lib/jcr_remote_sensing_klem

Li, J., \& Chen, W. (2005). A Rule-based Method for Mapping Canada's Wetlands Using Optical, Radar and DEM Data. International Journal of Remote Sensing, 26(22), 5051 - 5069. http://dx.doi.org/10.1080/01431160500166516

Mehrotra, S., Natenzon, C. E., Omojola, A., Folorunsho, R., Gilbride, J., \& Rosenzwig, C. (2009). Framework for City Climate Risk Assessment. Fifth Urban Research Symposium, Cities and Climate Change: Responding to an Urgent Agenda. Marseille, France. June, 2009. World Bank Commissioned Research, p. 80.

National Population Commission of Nigeria. (2006). The population of Local government areas (LGAs) of metropolitan Lagos (2006). Retrieved from www.citypopulation.de/Nigeria-Lagos.html

Neale, C. M. U., Wenger, D., Jayanthi, H., \& Farag, F. (2007). Mapping and Monitoring Wetlands using Airborne Multispectral Imagery. In Owe M., \& Neale C. (Eds), Proceedings of Symposium on Remote Sensing for Environmental Change Detection. International Association of Hydrological Sciences (IAHS) Publication, 316, 100-109.

Obiefuna, J. N., Nwilo, P. C., Atagbaza, A. O., \& Okolie, C. J. (2012). Land Cover Dynamics Associated with The Spatial Changes in the Wetlands of Lagos/Lekki Lagoon System of Lagos, Nigeria. Journal of Coastal Research. http://dx.doi.org/10.2112/JCOASTRES-D-12-00038.1

Odunuga, S., \& Oyebande, L. (2007). Change Detection and Hydrological Implications in the Lower Ogun Flood Plain, SW Nigeria. In Owe, M., \& Neale, C. (Eds). Proceedings of Symposium on Remote Sensing For Environmental Change Detection. International Association of Hydrological Sciences (IAHS) Publication, 316, 91-99.

Okude, A. S., \& Ademiluyi, I. A. (2006). Implications of the Changing Pattern of Land cover Of the Lagos Coastal Area of Nigeria. American-Eurasian Journal of Scientific Research, 1(1), 31 - 37.

Olaleye, J. B., Abiodun, O. E., \& Igbokwe, Q. C. (2009). Land Use Change Detection and Analysis Using Remotely Sensed Data in Lekki Peninsula Area of Lagos Nigeria. TS8B. SIM in Planning and Development, FIG Working Week 2009. Surveyors Key Role in Accelerated Development, Eliat, Israel, 3 - 8 May, 2009. p. 15. Retrieved from www.fig.net/pub/fig2009/papers/ts08b_olaleye_etal

Oyebande, L., Obot, E. O., Bodiliya, H. H., \& Shunsanya, C. O. (2003). An Inventory of Wetlands in Nigeria. World Conservation Union-IUCN, West African Regional Office, Ouagadougou, Burkina Faso.

Ozesmi, S. L., \& Bauer, M. E. (2002). Satellite Remote Sensing of Wetlands. Wetlands Ecology and Management, 10, 381 - 402. http://dx.doi.org/10.1023/A:1020908432489

Ramsar Convention Secretariat. (2007a). Ramsar Handbook for the Wise Use of Wetlands 'Toolkit' (3rd ed.). Ramsar Convention Secretariat, Gland, Switzerland. Retrieved from www. Ramsar.org/cda

Taiwo, O. J., \& Areola, O. (2009). A Spatial Temporal Analysis of Wetland Losses in the Lagos Coastal Region, southwestern Nigeria, using Multi-date satellite Imagery. Paper presented at IGARSS Annual Conference, Cape Town, South Africa, Sept. 2009.

The Presidential Committee for the Redevelopment of Lagos Megacity Region. (2006). Report of The Presidential Committee on the Redevelopment of Lagos Megacity Region. April, 2006. Federal Ministry of Housing and Urban Development. Abuja, p.86.

Uluocha, N. O., \& Okeke, I. C. (2004). Implications of Wetlands Degradation for Water Resources Management: Lessons from Nigeria. GeoJournal, 61, 151 - 154. http://dx.doi.org/10.1007/s10708-004-2868-3

UN-Habitat. (2010). Urban Development, Biodiversity and Wetland Management: Expert Workshop Report. Expert Workshop, 16 - 17 November, 2009. Kenya Wildlofe Training Institute, Naivasha, Kenya.

USEPA. (2009). What are Wetlands? Wetlands. Retrieved from http://www.epa.gov./owow/wetlands/vital/ 
what.html

Zhang, Q., Ban, Y., Liu, J., Shu, Q., \& Hu, Y. (2008). Analysis of Landscape Dynamics in Shanghai Using Landscape Metrics: Effects of Spatial Resolutions. The International Archives of the Photogrammetry, Remote Sensing and Spatial Information Sciences. Vol. XXXVII. Part B6b, Beijing 2008.

\section{Copyrights}

Copyright for this article is retained by the author(s), with first publication rights granted to the journal.

This is an open-access article distributed under the terms and conditions of the Creative Commons Attribution license (http://creativecommons.org/licenses/by/3.0/). 